\title{
Synthesis and Characterisation of Macrocycles Containing both Tetrazole and Pyridine Functionalities
}

\author{
Adrienne Fleming \\ Technological University Dublin \\ Jackie Gaire \\ Technological University Dublin \\ Fintan Kelleher \\ Technological University Dublin, fintan.kelleher@tudublin.ie
}

See next page for additional authors

Follow this and additional works at: https://arrow.tudublin.ie/ittsciart

Part of the Chemistry Commons

\section{Recommended Citation}

Fleming, A., Gaire, J., Kelleher, F., McGinley, J., McKee, V.: Synthesis and Characterisation of Macrocycles Containing both Tetrazole and Pyridine Functionalities. Tetrahedron,vol. 67 (8), 6 May 2011,p.3260-3266

This Article is brought to you for free and open access by the School of Science and Computing at ARROW@TU Dublin. It has been accepted for inclusion in Articles by an authorized administrator of ARROW@TU Dublin. For more information, please contact

arrow.admin@tudublin.ie, aisling.coyne@tudublin.ie, gerard.connolly@tudublin.ie.

Funder: Irish Government




Authors

Adrienne Fleming, Jackie Gaire, Fintan Kelleher, John McGinley, and Vickie McKee

This article is available at ARROW@TU Dublin: https://arrow.tudublin.ie/ittsciart/13 


\title{
Synthesis and characterisation of macrocycles containing both tetrazole and pyridine functionalities
}

Adrienne Fleming, ${ }^{\mathrm{a}}$ Jackie Gaire, ${ }^{\mathrm{a}}$ Fintan Kelleher, ${ }^{\mathrm{a}} \mathrm{John}$ McGinley, ${ }^{\mathrm{b},{ }^{*}}$ and Vickie McKee. ${ }^{\mathrm{c}}$

a Molecular Design and Synthesis Group, Department of Science, Institute of Technology Tallaght, Dublin 24, Ireland,

${ }^{b}$ Department of Chemistry, National University of Ireland Maynooth, Maynooth, Co. Kildare, Ireland, and

${ }^{c}$ Department of Chemistry, Loughborough University, Loughborough, Leicestershire LE11 3TU, $U K$.

\begin{abstract}
The syntheses of tetra-tetrazole macrocycles containing at least one 2,6-bis(tetrazole)pyridine unit, linked by a variety of $n$-alkyl ( $n=3,5,7$ or 9 carbon atoms) chain lengths, are described. There has been no previous incorporation of the pyridine moiety into a tetra-tetrazolophane macrocycle. The crystal structure of one such tetra-tetrazole macrocycle has also been structurally characterised and revealed a bowl-shaped conformation.
\end{abstract}

\section{Keywords}

Tetrazole, macrocycles, pyridine, synthesis, X-ray structure. 


\section{Introduction}

There are many articles and reviews on tetrazoles in the literature, including their use as carboxylic acid bioisosteres in drug discovery and as functional ligands in coordination chemistry. ${ }^{1-5}$ The development of "click" chemistry methodology, as described by Sharpless and co-workers, ${ }^{6,7}$ has resulted in a recent increase in tetrazole structures, which suggests that molecular recognition studies of tetrazoles will become increasingly important. ${ }^{8-15} \mathrm{We}$ are interested in tetrazoles as precursors for the formation of new functionalised polytetrazole macrocycles, which could find application, for example, as sensors or in molecular recognition. We have previously reported the synthesis and structural characterisation of tetra-tetrazole macrocycles from 1,2-, 1,3- and 1,4-dicyanobenzene derivatives as well as the first example of a host-guest interaction between a tetra-tetrazole macrocycle and a solvent molecule. ${ }^{16-18}$ Previous work in our group has shown that the use of odd-numbered carbon chains gave higher yields than when even-numbered chains were used. ${ }^{18}$ This paper focuses on the synthesis and characterisation of bis-tetrazoles from 2,6-pyridinedicarbonitrile (1), their $n$-alkyl halide derivatives (where $n=3,5,7$ or 9), and their resulting tetra-tetrazole macrocycles (see Scheme 1). To our knowledge, there has been no previous incorporation of the pyridine moiety into a tetra-tetrazolophane macrocycle. The X-ray crystal structure of one such macrocyclic derivative (7c), which is obtained from the reaction of $\mathbf{3 c}$ with 1,3-bis(tetrazol-5-yl)benzene (6), is also described. 


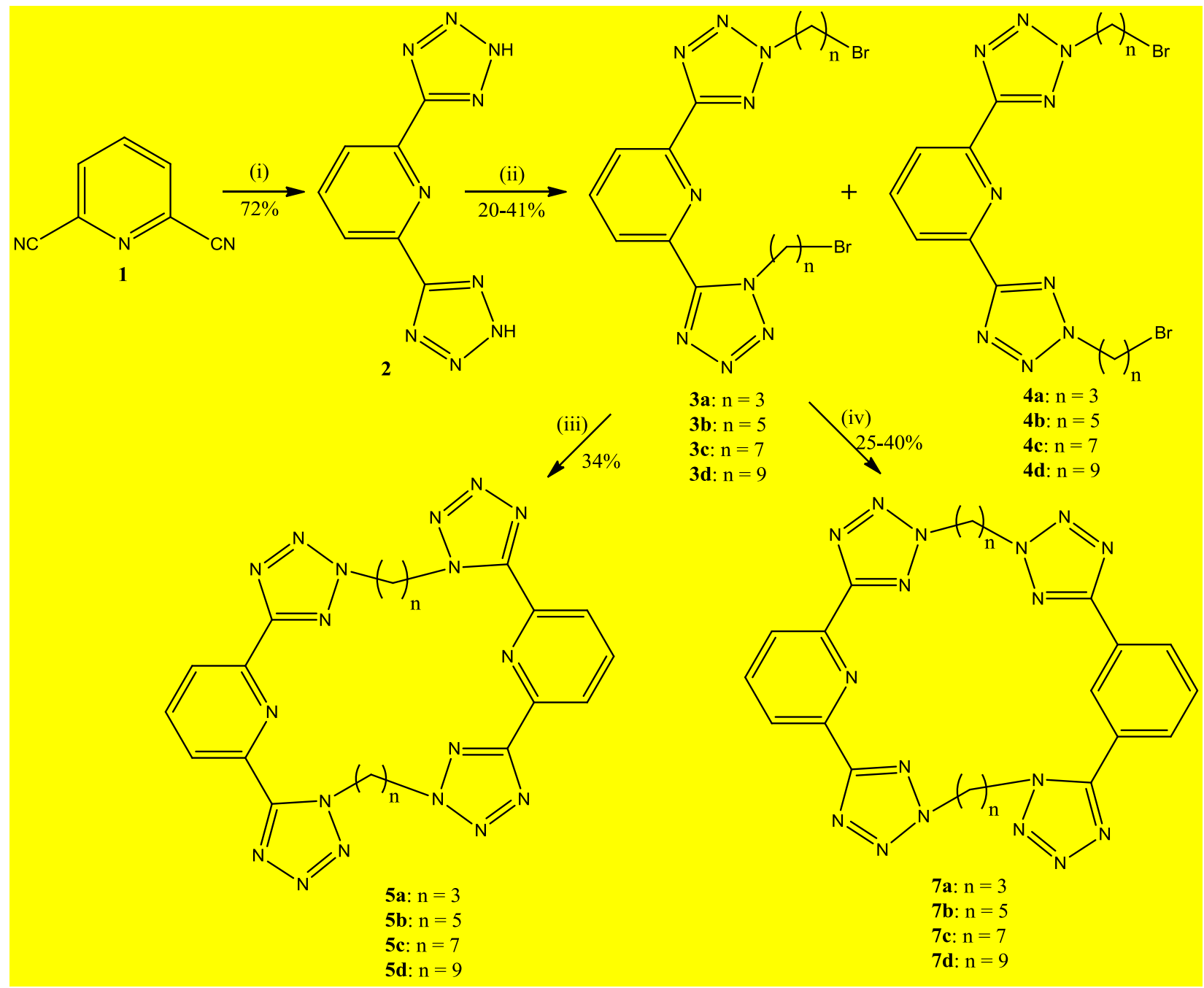

Scheme 1. Reagents and conditions: (i) $\mathrm{NaN}_{3}, \mathrm{NH}_{4} \mathrm{Cl}, \mathrm{LiCl}, \mathrm{DMF}, 110{ }^{\circ} \mathrm{C}, 10 \mathrm{~h}$; (ii) 1,ndibromoalkane ( $\mathrm{n}=3,5,7,9$ ), $\mathrm{Et}_{3} \mathrm{~N}, \mathrm{MeOH}, \Delta, 24 \mathrm{~h}$; (iii) $2, \mathrm{~K}_{2} \mathrm{CO}_{3}, \mathrm{DMF}, 75{ }^{\circ} \mathrm{C}, 24 \mathrm{~h}$; iv) 6 , $\mathrm{K}_{2} \mathrm{CO}_{3}$, DMF, $75^{\circ} \mathrm{C}, 24 \mathrm{~h}$.

\section{Results and Discussion}

\section{Syntheses and characterisation of bis-tetrazoles}

The reaction of 2,6-pyridinedicarbonitrile (1) with sodium azide was carried out, following a similar procedure to that we have previously described, ${ }^{19}$ to give 2,6-di( $2 \mathrm{H}$-tetrazol-5-yl)pyridine (2) in good yield. The IR spectrum of 2 showed the indicative loss of the nitrile and azide bands at $c a .2200$ and $c a .2060 \mathrm{~cm}^{-1}$, respectively. The ${ }^{1} \mathrm{H}$ NMR spectrum of 2 showed a multiplet at $8.32 \mathrm{ppm}$ due to the pyridyl ring proton signals, and a broad singlet at $3.56 \mathrm{ppm}$ due to the $\mathrm{NH}$ 
proton. The ${ }^{13} \mathrm{C}$ NMR spectrum confirmed the formation of the tetrazole system with the signal at $158.5 \mathrm{ppm}$, indicative of the tetrazole moiety. ${ }^{16-19}$

The alkylation of $\mathbf{2}$ was carried out using the appropriate $\alpha, \omega$-dibromoalkane in the presence of triethylamine as base in methanol for three hours at reflux temperature. In each case, after cooling and reaction work-up, only two products were obtained, which were purified by column chromatography on silica gel. These products were the N2,N1' (major) (3a-d) and N2,N2' (minor) (4a-d) di-alkylated systems. The melting points of the symmetric and asymmetric products differed. It was observed that the symmetric analogues N2,N2' had slightly higher melting point values, which may have been due to the symmetric system experiencing greater intermolecular bonding.

The range of asymmetric product yields (3a-d) varied from 17\%-37\% (see experimental) and were considerably higher than the symmetric products (4a-d). It was observed that as the chain length increased the yield also increased. This may be due to the possibility of the species containing shorter chains forming polymeric adducts. The IR spectra of 3a-d showed the characteristic bands of the tetrazole at 1668,1523 and $1254 \mathrm{~cm}^{-1}$ and the $>\mathrm{C}=\mathrm{N}-$ band of the pyridine at $1458 \mathrm{~cm}^{-1}$ respectively. The ${ }^{1} \mathrm{H}$ NMR spectra of 3a-d clearly showed the asymmetry that is present in the products. The aromatic protons that are ortho to the tetrazole rings are both split into two separate doublets at $8.50 \mathrm{ppm}$, beside the N1 tetrazole ring, and at $8.38 \mathrm{ppm}$ for the $\mathrm{N} 2$ tetrazole ring of 3a. The pseudo-triplet signal for the remaining proton on the pyridine ring at $8.12 \mathrm{ppm}$ is not affected by asymmetry, probably due to its distance from the point of asymmetry. The methylene groups directly attached to the tetrazole ring appear as two separate triplets in the ${ }^{1} \mathrm{H}$ NMR spectra of 3a-d with the N1- $\mathrm{CH}_{2}$ triplet being observed at $5.25 \mathrm{ppm}$ and the $\mathrm{N} 2-\mathrm{CH}_{2}$ signal being observed at $4.96 \mathrm{ppm}$ in 3a. The signal associated with the $\mathrm{CH}_{2} \mathrm{Br}$ appeared at $\sim 3.4$ ppm as a multiplet in all compounds in the series apart from compound 3a, where two triplets at $3.62 \mathrm{ppm}$ and $3.51 \mathrm{ppm}(\mathrm{N} 1$ and N2) were observed. This was probably due to the short distance from the $\mathrm{N} 1$ and $\mathrm{N} 2$ alkylated tetrazoles to the $\mathrm{CH}_{2} \mathrm{Br}$. As a comparison, in the ${ }^{1} \mathrm{H} \mathrm{NMR}$ spectra of the 1,3-bis[(bromoalkylyl)tetrazol-5-yl]benzene $\left(2-N, 2-N{ }^{\prime}\right),{ }^{18}$ the $\mathrm{N} 2-\mathrm{CH}_{2}$ signals appear at $\sim 4.70$ ppm while those for the $\mathrm{CH}_{2} \mathrm{Br}$ appear at $\sim 3.40 \mathrm{ppm}$. All other methylene signals can be observed as multiplets between 2.1-1.3 ppm. The ${ }^{13} \mathrm{C}$ NMR spectra of 3a-d also showed the asymmetric nature of the product with two tetrazole peaks at $\sim 164 \mathrm{ppm}$ for the N2 substituted tetrazole and $\sim 151 \mathrm{ppm}$ for the N1 substituted tetrazole. 
The ${ }^{1} \mathrm{H}$ NMR spectra for the symmetric bis-tetrazoles 4a-d are much simpler that those observed for the asymmetric bis-tetrazoles 3a-d, just discussed. The aromatic protons, ortho to the tetrazole rings, appear as as a single doublet at $\sim 8.36 \mathrm{ppm}$ while the remaining proton on the pyridine ring appears as a triplet at $\sim 8.38 \mathrm{ppm}$. Furthermore, the methylene groups directly attached to the tetrazole ring now appear as a single triplet in the ${ }^{1} \mathrm{H}$ NMR spectra of $\mathbf{4 a - d}$ at 4.95 ppm for $\mathbf{4 a}$ and at $\sim 4.75 \mathrm{ppm}$ for $\mathbf{4 b - d}$. The ${ }^{13} \mathrm{C}$ NMR spectra confirmed the symmetric nature of the compounds with a signal at $164.4 \mathrm{ppm}$, due to the tetrazoles being substituted in the N2 position. The IR spectra of 4a-d were very similar to those of the asymmetric derivatives. Apart from the NMR spectra, the other major difference between the asymmetric and symmetric derivatives was in the yield of material recovered. The yield of the symmetric products 4a-d was surprisingly low, falling in the range of 2-5\%. One possible reason for these low yields in the symmetric cases may be the presence of a pyridinium salt, formed during the acidification work-up of the bis-tetrazole derivative 2. Due to the difference in pKa between pyridine (ca. pKa 5.2) and tetrazole ( $c a$. pKa 4.5), it is believed that the pyridine nitrogen will be protonated. However, this does not explain the difference in yield between the asymmetric and symmetric derivatives, as this pyridinium salt would also have been present in the reaction.

\section{$X$-Ray crystal structure of $3 b$}

Crystals of compound $\mathbf{3 b}$, suitable for an X-ray diffraction study, were obtained as colourless plates by the diffusion method of chloroform in methanol. The diffraction data were of poor quality but the significant features of the structure are clear. The structure confirmed the presence of the pendant bromoalkyl groups substituted in the N2,N1' positions, see Figure 1. 


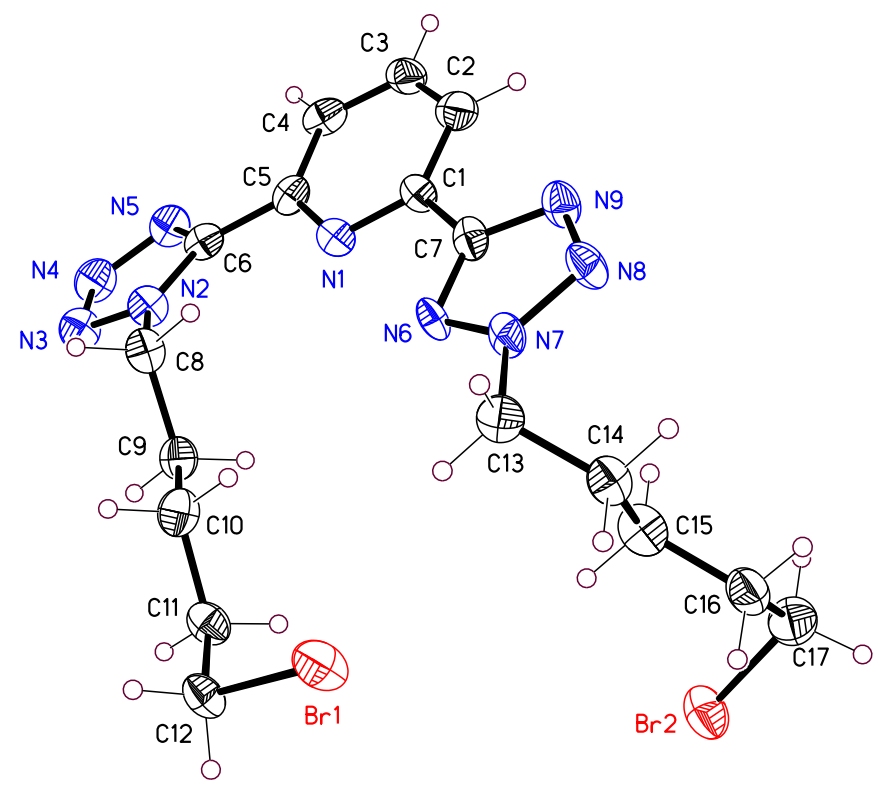

Figure 1. Molecular structure of $\mathbf{3 b}$ with displacement ellipsoids at the 50\% probability level for non-H atoms.

One of the tetrazole rings and the pyridine ring are almost co-planar, with the other tetrazole ring being distinctly tilted relative to the other two rings. Both bromohexyl arms lie on the same face of the pyridine ring. A $\pi-\pi$ interaction between neighbouring molecules is observed and shown in Figure 2.

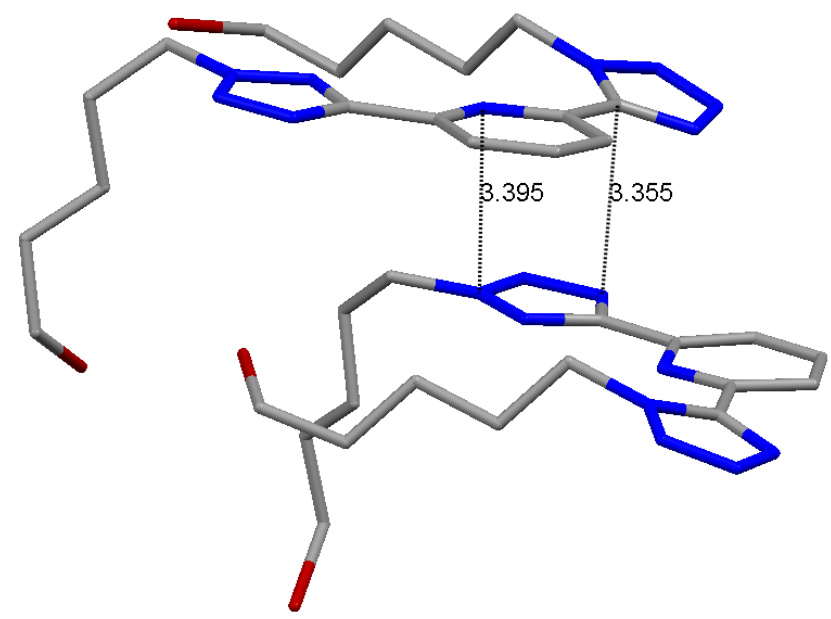

Figure 2. Observed $\pi-\pi$ interaction of $\mathbf{3 b}$.

Synthesis of pyridyl-tetra-tetrazole macrocycles 
Since the yields of the asymmetric alkylated bis-tetrazoles (3a-d) were substantially better than those of the symmetric derivatives, it was decided to attempt the synthesis of an asymmetric pyridine tetra-tetrazole macrocycle. When an asymmetric alkylated product (3a-d) was reacted with 2,6-bis-(2H-tetrazol-5-yl)-pyridine (2) using previously reported conditions, ${ }^{18}$ a number of products were observed by TLC analysis. However, these products could not be separated by conventional chromatography methods. This may have been due to the likelihood of pyridine macrocycles (N2,N1',N2",N1"') and (N2,N1',N1",N2'") having similar $\mathrm{R}_{\mathrm{f}}$ values. The ${ }^{1} \mathrm{H}$ NMR spectra of the single spot by TLC for each of the tetra-tetrazole macrocycles (5a-d) were very complicated but clearly showed signals for two macrocycles (N2,N1',N2",N1"') and $\left(\mathrm{N} 2, \mathrm{~N} 1{ }^{\prime}, \mathrm{N} 1 ", \mathrm{~N} 2{ }^{\prime \prime}\right)$.

We have previously reported the synthesis and structural characterisation of tetra-tetrazole macrocycles from 1,2-, 1,3- and 1,4-dicyanobenzene derivatives, using alkyl linkers. ${ }^{16,18}$ The cyclisation reaction, in all cases, formed predominantly the symmetric product, where the alkyl chains are joined to the tetrazole moieties at the N2 position, with very little asymmetry being observed. It was therefore postulated that if the asymmetric alkylated products (3a-d) were clipped with 1,3-bis(tetrazol-5-yl)benzene (6) that one major product would be obtained, which was the alkylation of the $2 \mathrm{~N}, 2 \mathrm{~N}^{\prime}$ positions of 1,3-bis(tetrazol-5-yl)benzene (see Experimental section). The major products in all of these reactions were the (N2,N2',N2",N1'") macrocycles (7a-d), with high yields of $\sim 40 \%$ in all cases, except in the case of $\mathbf{7 d}$ which is probably due to the difficulty in forming the large ring system. The HRMS results obtained for the four products (7a-d) confirmed the formation of the macrocycles.

The IR spectra of 7a-d were very similar to those of the alkylated precursors (3a-d) with characteristic shifts for pyridine, tetrazole and phenyl ring systems being observed (see Experimental). In the ${ }^{1} \mathrm{H}$ NMR spectra of all the cyclisation products, the signal for the $\mathrm{CH}_{2} \mathrm{Br}$ at $\sim 3.4 \mathrm{ppm}$ had disappeared, and the accompanying loss of the $\mathrm{CH}_{2} \mathrm{Br}$ signal in the ${ }^{13} \mathrm{C} \mathrm{NMR}$ spectra confirmed that cyclisation had occurred. The ${ }^{1} \mathrm{H}$ NMR spectra of 7a-d have a complex aromatic region. The signals in the ${ }^{1} \mathrm{H}$ NMR spectrum of $7 \mathbf{a}$ at $8.41(\mathrm{~s}), 8.17(\mathrm{~d})$ and $7.60(\mathrm{t}) \mathrm{ppm}$ are due to the protons of the phenyl ring while those at 8.31(d), 8.04(d) and 7.91(t) ppm are due to the protons on the pyridine ring. The aromatic regions in the ${ }^{1} \mathrm{H}$ NMR spectra of $7 \mathbf{b}-\mathbf{d}$ are similar. The asymmetric nature of the macrocycle is observed by the appearance of two sets of doublets for the pyridine protons ortho to the different tetrazole rings. This asymmetry also 
manifests itself in the signals of the methylene groups attached to the tetrazole rings. A triplet is observed at $5.30 \mathrm{ppm}$ for the methylene protons attached to the tetrazole ring at N1. A multiplet for the methylene protons attached to the symmetric 1,3-bis(tetrazol-5-yl)benzene is observed at $5.03 \mathrm{ppm}$. Another multiplet is observed at $4.74 \mathrm{ppm}$ for the methylene group bonded to the second tetrazole attached to the pyridine group. These two multiplets at 5.03 and $4.74 \mathrm{ppm}$ are not observed as the alkyl chain increases, presumably because the environment in which the methylene groups attached to the N2-tetrazole becomes similar. In compounds $7 \mathbf{b}-\mathbf{d}$, a single multiplet is observed at $c a$. $4.70 \mathrm{ppm}$, which accounts for the 6 protons associated with the N2$\mathrm{CH}_{2}$ substituted tetrazoles. The remaining alkyl protons appear at $1.67 \mathrm{ppm}$. With increased alkyl chain length further multiplets can be observed at $c a .2 .10 \mathrm{ppm}$.

The ${ }^{13} \mathrm{C}$ NMR spectra of 7a-d confirmed the macrocyclic structure with three signals observed at 164.6, 164.2 and $163.9 \mathrm{ppm}$, respectively, for the N2-substituted tetrazoles. A single signal was observed at $151.5 \mathrm{ppm}$ for the N1-substituted tetrazole, confirming the substitution pattern of the macrocycles. Furthermore, four peaks are observed for the methylene carbons adjacent to the tetrazole nitrogens at 51.3, 50.4 and 49.4 ppm for the $\mathrm{N} 2$ substituted tetrazoles and $46.1 \mathrm{ppm}$ for the N1 substituted tetrazole.

\section{$X$-Ray Crystal Structure of $7 c$}

Crystals of 7c were obtained from chloroform solution, and the crystal structure confirms the expected tetra-tetrazole macrocyclic structure, with three of the tetrazole rings substituted at the $\mathrm{N} 2$ position and one tetrazole ring substituted at the $\mathrm{N} 1$ position, as suggested by ${ }^{13} \mathrm{C} \mathrm{NMR}$ spectroscopy (Figure 3). The structure also shows that N8 of one tetrazole ring and N9 of the pyridine ring are potentially available for use as metal ion chelators. 


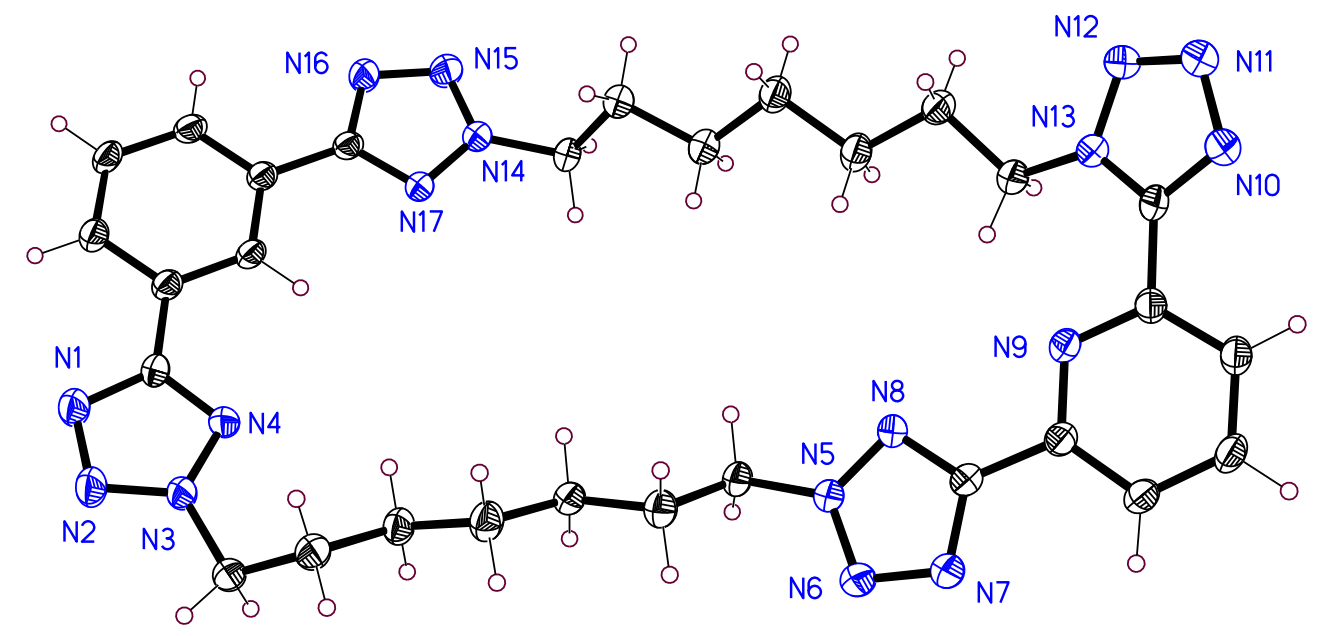

Figure 3. Molecular structure of 7c with displacement ellipsoids at the $50 \%$ probability level for non-H atoms.

Bond lengths and angles are similar to other tetrazole macrocyclic compounds we have previously reported. ${ }^{16,18}$ One striking difference between $\mathbf{7 c}$ and a macrocycle which contains two phenyl rings, such as $\mathbf{8},{ }^{16}$ is the overall geometry of both macrocycles, which is bowl-shaped in the case of 7c (Figure 4) but is more step-like in $\mathbf{8}$ (Figure 5). This geometry change is likely to be a packing effect due to the different alkyl chain lengths. Furthermore, there is now only one $\pi-\pi$ interaction present between the ring containing N10-N13 and its symmetry equivalent (under symmetry operation $1-\mathrm{x}, 1-\mathrm{y}, \mathrm{z}$ ), with a centroid-centroid distance of $3.478 \AA$, which results in the packing arrangement shown in Figure 7. This type of arrangement is different to that observed in $\mathbf{8}$ where adjacent macrocycles are arranged so that one benzene-tetrazole unit lies over the cavity of the adjacent macrocycle (Figure 5), forming a local stacking arrangement.

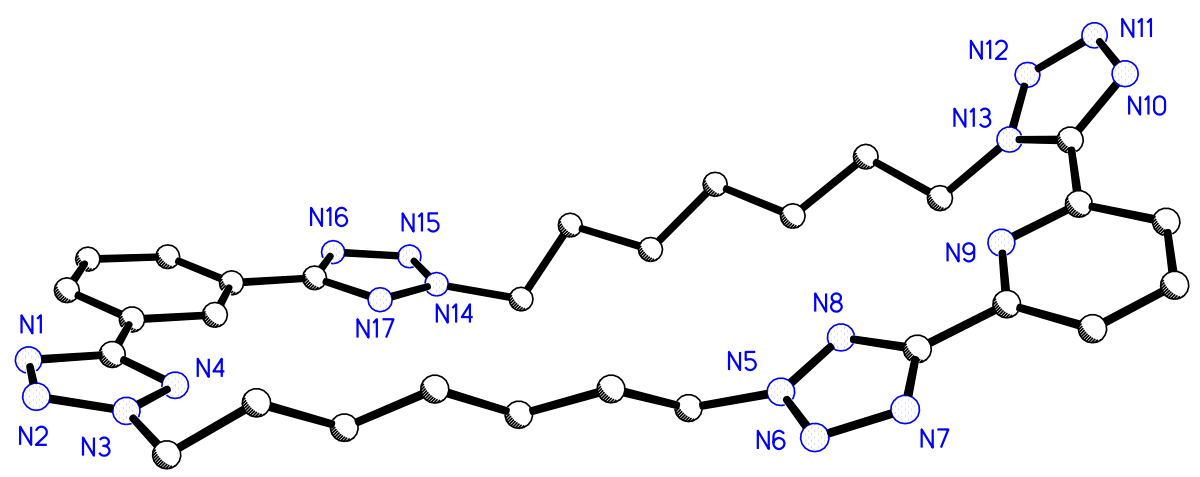

Figure 4. Side view of 7c. 

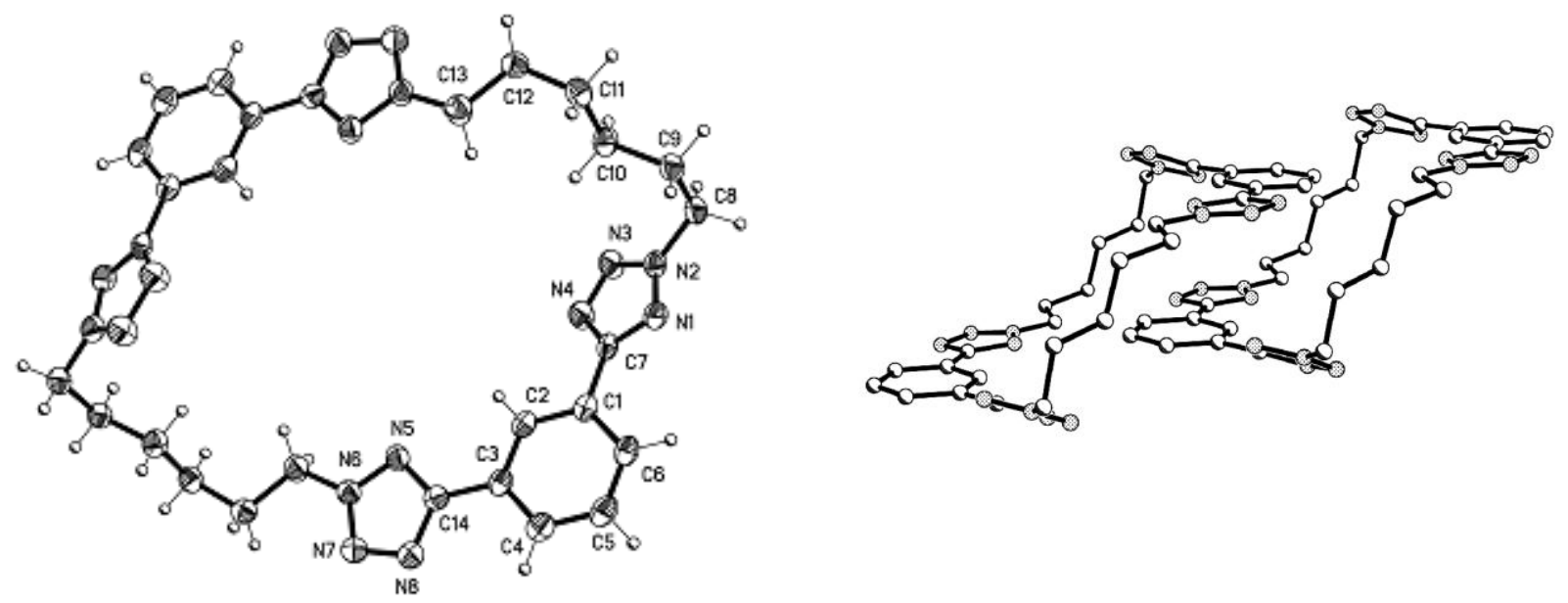

Figure 5. Molecular structure of $\mathbf{8}$ showing displacement ellipsoids at the 50\% probability level for non-H atoms (left), and a stacking interaction between adjacent macrocycles in $\mathbf{8}$ (right). ${ }^{16}$

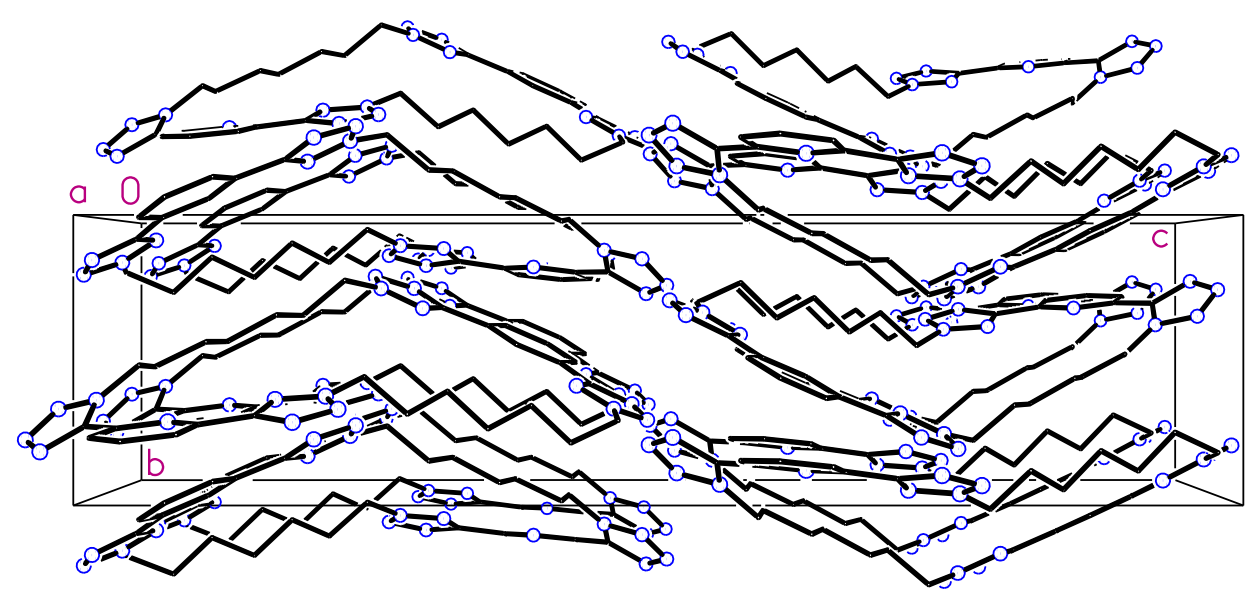

Figure 6. Unit cell of 7c viewed down the $a$ axis, showing the packing arrangement of the macrocycle.

\section{Conclusions}

In this paper, we have reported the syntheses and characterisation of bromo-alkyl derivatives of 2,6-bis(tetrazole)pyridine, where the alkyl chain contains either 3, 5, 7 or 9 carbons atoms. Interestingly, the predominant compound formed in these reactions is the asymmetric 1-N,2- $N$ 'bistetrazole isomer, whereas the same reactions carried out with 1,3-bis(tetrazole)benzene have previously yielded symmetric 2-N,2- $N$ '-bistetrazole derivatives. Four new tetra-tetrazole macrocycles, containing one pyridine ring, were synthesised and the X-ray crystal structure of 
one such macrocycle (7c) showed a bowl-shaped conformation. Complexation studies of these new tetra-tetrazole macrocycles with various metal ions are currently being undertaken.

\section{Experimental}

All reagents and solvents were commercially obtained and used without further purification. The petroleum ether used for chromatography was $40: 60$ reagent grade. ${ }^{1} \mathrm{H}$ and ${ }^{13} \mathrm{C}$ NMR $(\delta$ ppm; $J$ $\mathrm{Hz}$ ) spectra were recorded on a JEOL JNM-LA300 FT-NMR spectrometer using saturated $\mathrm{CDCl}_{3}$ solutions with $\mathrm{Me}_{4} \mathrm{Si}$ reference, unless indicated otherwise. Infrared spectra $\left(\mathrm{cm}^{-1}\right)$ were recorded as $\mathrm{KBr}$ discs or liquid films between $\mathrm{KBr}$ plates using a Nicolet Impact 410 FT-IR spectrophotometer. Melting point analysis was carried out using either a Stewart Scientific SMP1 or a Mettler FP62 melting point apparatus and are uncorrected. Microanalysis was carried out at the Microanalytical Laboratory of University College, Dublin. Mass spectrometry was carried out at the Centre for Synthesis and Chemical Biology (CSCB), University College, Dublin using Quattro micro $^{\mathrm{TM}}$ LC-MS/MS and LCT mass spectrometers. Standard Schlenk techniques were used throughout. The synthesis of compounds $6^{19}$ has been described previously.

CAUTION: Owing to their potentially explosive nature, all preparations of and subsequent reactions with azides and tetrazoles were conducted under an inert atmosphere behind a rigid safety screen.

Synthesis of 2,6-di(2H-tetrazol-5-yl)pyridine (2)

A suspension of 2,6-pyridinedicarbonitrile $(2.57 \mathrm{~g}, 20 \mathrm{mmol})$, sodium azide $(2.86 \mathrm{~g}, 43 \mathrm{mmol})$, ammonium chloride $(2.35 \mathrm{~g}, 43 \mathrm{mmol})$ and lithium chloride $(0.6 \mathrm{~g}, 14 \mathrm{mmol})$ in anhydrous dimethylformamide $(60 \mathrm{~mL})$ was stirred for 10 hours at $110{ }^{\circ} \mathrm{C}$. After this time, the solution was cooled and the insoluble salts were removed by filtration. The solvent was then evaporated under reduced pressure and the residue was dissolved in deionised water $(200 \mathrm{~mL})$ and acidified with concentrated $\mathrm{HCl}(3 \mathrm{~mL})$, to initiate precipitation. The product was filtered, washed with water (3 x $40 \mathrm{~mL}$ ) and dried to give 2,6-di(2H-tetrazol-5-yl)pyridine (2) as a white crystalline powder. Purification by recrystallisation from methanol to give white needles of 2 (3.08 g, $14.3 \mathrm{mmol}, 72$ $\%) ; \mathrm{mp}>300{ }^{\circ} \mathrm{C}$; IR $\left(\mathrm{KBr} \mathrm{cm}^{-1}\right) 3415(\mathrm{~N}-\mathrm{H}), 2851,1654,1596,1458,1278 ;{ }^{1} \mathrm{H}$ NMR (300 $\left.\mathrm{MHz},\left(\mathrm{CD}_{3}\right)_{2} \mathrm{SO}\right): \delta_{\mathrm{H}} 8.49(1 \mathrm{H}, \mathrm{t}, J=7.8 \mathrm{~Hz}, \mathrm{ArH}), 8.23(2 \mathrm{H}, \mathrm{d}, J=7.6 \mathrm{~Hz}, \operatorname{Ar} H), 3.56(2 \mathrm{H}, \mathrm{s}$ 
(br), $\mathrm{NH}) ;{ }^{13} \mathrm{C}$ NMR $\left(75.4 \mathrm{MHz},\left(\mathrm{CD}_{3}\right)_{2} \mathrm{SO}\right): \delta_{\mathrm{C}} 158.5,145.5,142.9,119.3,125.4$. Anal. Calcd for $\mathrm{C}_{7} \mathrm{H}_{5} \mathrm{~N}_{9}$ : C, 39.07; H, 2.34; N, 58.59\%. Found C, 38.98; H, 2.36; N, 58.45\%.

General Syntheses of alkylated bis-tetrazoles ( $3 \& 4)$

Compound $2(1.51 \mathrm{~g}, 7.0 \mathrm{mmol})$ was dissolved in methanol $(60 \mathrm{ml})$ and to the stirred solution was added triethylamine $(4.23 \mathrm{ml}, 42 \mathrm{mmol})$. The resulting solution was stirred at reflux temperature for 30 minutes, then to the hot solution was added the corresponding dibromoalkane (21.0 mmol). The reaction mixture was then stirred at reflux for a further 24 hours. On cooling, the solid was removed by filtration and the solvent was removed from the filtrate under vacuum. The resulting products were purified by column chromatography on silica gel (initially @ a ratio of petroleum ether:ethyl acetate 70:30, followed by the ratio 60:40).

2-[2-(3-Bromopropyl)-2H-tetrazol-5-yl]-6-[1-(3-bromopropyl)-1H-tetrazol-5-yl]pyridine (3a)

White solid (0.55 g, $1.2 \mathrm{mmol}, 17.2 \%)$; mp 88-90 ${ }^{\circ} \mathrm{C} ; R_{f}=0.32$ (60:40 petroleum ether/ethyl acetate); IR (KBr, cm $\left.{ }^{-1}\right): 2968,1668(>\mathrm{C}=\mathrm{N}-), 1523(-\mathrm{N}=\mathrm{N}-), 1458(\mathrm{C}=\mathrm{N}$, pyridine), 1434, 1254; ${ }^{1} \mathrm{H}$ NMR (300 MHz, $\left.\mathrm{CDCl}_{3}\right): \delta_{\mathrm{H}} 2.67\left(4 \mathrm{H}, \mathrm{m}, \mathrm{CH}_{2}\right), 3.51\left(2 \mathrm{H}, \mathrm{t}, J=6.1 \mathrm{~Hz}, \mathrm{CH}_{2} \mathrm{Br}(\mathrm{N} 2)\right), 3.62$ $\left(2 \mathrm{H}, \mathrm{t}, J=6.6 \mathrm{~Hz}, \mathrm{CH}_{2} \mathrm{Br}(\mathrm{N} 1)\right), 4.96\left(2 \mathrm{H}, \mathrm{t}, J=6.6 \mathrm{~Hz}, \mathrm{CH}_{2} \mathrm{~N} 2\right), 5.25(2 \mathrm{H}, \mathrm{t}, J=6.7 \mathrm{~Hz}$, $\left.\mathrm{CH}_{2} \mathrm{~N} 1\right), 8.12(1 \mathrm{H}, \mathrm{t}, J=7.8 \mathrm{~Hz}, \mathrm{py} H), 8.38(1 \mathrm{H}, \mathrm{d}, J=7.8 \mathrm{~Hz}, \mathrm{py} H), 8.50(1 \mathrm{H}, \mathrm{d}, J=7.8 \mathrm{~Hz}$, py $H) ;{ }^{13} \mathrm{C}$ NMR $\left(75.4 \mathrm{MHz}, \mathrm{CDCl}_{3}\right): \delta_{\mathrm{C}} 28.7,29.3,31.9,32.9,48.9,51.6,124.0,125.3,138.5$, 145.0, 146.7, 151.4, 164.1. Anal. Calcd for $\mathrm{C}_{13} \mathrm{H}_{15} \mathrm{~N}_{9} \mathrm{Br}_{2}$ : C, 34.16; H, 3.31; N, 27.58\%. Found: C, 34.48; H, 3.44; N, $27.21 \%$.

2,6-Bis[2-(3-bromopropyl)-2H-tetrazol-5-yl]-pyridine (4a)

White solid (0.10 g, $0.22 \mathrm{mmol}, 3.1 \%) ; \mathrm{mp} 94-96{ }^{\circ} \mathrm{C} ; R_{f}=0.21$ (60:40 petroleum ether/ethyl acetate); IR ( $\left.\mathrm{KBr}, \mathrm{cm}^{-1}\right)$ : 2922, 2855, $1648(>\mathrm{C}=\mathrm{N}-), 1587(-\mathrm{N}=\mathrm{N}-), 1459(\mathrm{C}=\mathrm{N}$, pyridine), 1436, 1263; ${ }^{1} \mathrm{H}$ NMR $\left(300 \mathrm{MHz}, \mathrm{CDCl}_{3}\right): \delta_{\mathrm{H}} 2.68\left(4 \mathrm{H}, \mathrm{q}, J=6.1 \mathrm{~Hz}, \mathrm{CH}_{2}\right), 3.48(4 \mathrm{H}, \mathrm{t}, J=6.8 \mathrm{~Hz}$, $\left.\mathrm{CH}_{2} \mathrm{Br}\right), 4.95\left(4 \mathrm{H}, \mathrm{t}, J=6.8 \mathrm{~Hz}, \mathrm{CH}_{2} \mathrm{~N}\right), 8.02(1 \mathrm{H}, \mathrm{t}, J=7.8 \mathrm{~Hz}, \mathrm{pyH}), 8.37(2 \mathrm{H}, \mathrm{d}, J=7.8 \mathrm{~Hz}$, py $H) ;{ }^{13} \mathrm{C} \mathrm{NMR}\left(75.4 \mathrm{MHz}, \mathrm{CDCl}_{3}\right): \delta_{\mathrm{C}} 29.7,31.8,51.7,123.8,138.5,148.3$, 164.4. Anal. Calcd for $\mathrm{C}_{13} \mathrm{H}_{15} \mathrm{~N}_{9} \mathrm{Br}_{2}$ : C, 34.16; H, 3.31; N, 27.58\%. Found: C, 34.38; H, 3.24; N, 27.24\%. 
White solid (1.21 g, $2.36 \mathrm{mmol}, 33.6 \%) ; \mathrm{mp} \mathrm{78-80}{ }^{\circ} \mathrm{C} ; R_{f}=0.41$ (60:40 petroleum ether/ethyl acetate); IR (KBr, cm $\left.{ }^{-1}\right): 2925,2857,1651(>\mathrm{C}=\mathrm{N}-), 1582(-\mathrm{N}=\mathrm{N}-), 1460(\mathrm{C}=\mathrm{N}$, pyridine $), 1434$, 1261; ${ }^{1} \mathrm{H}$ NMR (300 MHz, $\left.\mathrm{CDCl}_{3}\right): \delta_{\mathrm{H}} 1.71\left(4 \mathrm{H}, \mathrm{m}, \mathrm{CH}_{2}\right), 1.93\left(4 \mathrm{H}, \mathrm{m}, \mathrm{CH}_{2}\right), 2.17\left(4 \mathrm{H}, \mathrm{m}, \mathrm{CH}_{2}\right)$, $3.42\left(4 \mathrm{H}, \mathrm{m}, \mathrm{CH}_{2} \mathrm{Br}\right), 4.76\left(2 \mathrm{H}, \mathrm{t}, J=7.1 \mathrm{~Hz}, \mathrm{CH}_{2} \mathrm{~N} 2\right), 5.16\left(2 \mathrm{H}, \mathrm{t}, J=7.8 \mathrm{~Hz}, \mathrm{CH}_{2} \mathrm{~N} 1\right), 8.12$ $(1 \mathrm{H}, \mathrm{t}, J=7.8 \mathrm{~Hz}, \mathrm{py} H), 8.36(1 \mathrm{H}, \mathrm{d}, J=6.9 \mathrm{~Hz}, \mathrm{py} H), 8.49(1 \mathrm{H}, \mathrm{d}, J=6.9 \mathrm{~Hz}, \mathrm{py} H) ;{ }^{13} \mathrm{C} \mathrm{NMR}$ $\left(75.4 \mathrm{MHz}, \mathrm{CDCl}_{3}\right): \delta_{\mathrm{C}} 25.0,26.4,27.2,27.9,28.6,28.9,29.7,32.9,49.8,53.3,123.9,125.2$, 138.8, 145.2, 146.9, 151.2, 164.0. Anal. Calcd for $\mathrm{C}_{17} \mathrm{H}_{23} \mathrm{~N}_{9} \mathrm{Br}_{2}$ : C, 39.78; H, 4.52; N, $24.56 \%$. Found: C, 39.83; H, 4.46; N, 24.53\%.

2,6-Bis-[2-(5-bromopentyl)-2H-tetrazol-5-yl]-pyridine (4b)

White solid (0.10 g, $0.2 \mathrm{mmol}, 2.8 \%)$; mp 82-84 ${ }^{\circ} \mathrm{C} ; R_{f}=0.32$ (60:40 petroleum ether/ethyl acetate); IR (KBr, cm $\left.{ }^{-1}\right): 2926,2856,1649(>\mathrm{C}=\mathrm{N}-), 1581(-\mathrm{N}=\mathrm{N}-), 1462(\mathrm{C}=\mathrm{N}$, pyridine $), 1435$, 1258; ${ }^{1} \mathrm{H}$ NMR $\left(300 \mathrm{MHz}, \mathrm{CDCl}_{3}\right): \delta_{\mathrm{H}} 1.68\left(4 \mathrm{H}, \mathrm{m}, \mathrm{CH}_{2}\right), 1.91\left(4 \mathrm{H}, \mathrm{m}, \mathrm{CH}_{2}\right), 2.19\left(4 \mathrm{H}, \mathrm{m}, \mathrm{CH}_{2}\right)$, $3.41\left(4 \mathrm{H}, \mathrm{t}, J=6.6 \mathrm{~Hz}, \mathrm{CH}_{2} \mathrm{Br}\right), 4.77\left(4 \mathrm{H}, \mathrm{t}, J=7.1 \mathrm{~Hz}, \mathrm{CH}_{2} \mathrm{~N}\right), 8.06(1 \mathrm{H}, \mathrm{t}, J=7.8 \mathrm{~Hz}, \mathrm{pyH})$, $8.45(2 \mathrm{H}, \mathrm{d}, J=7.8 \mathrm{~Hz}, \mathrm{py} H) ;{ }^{13} \mathrm{C} \mathrm{NMR}\left(75.4 \mathrm{MHz}, \mathrm{CDCl}_{3}\right): \delta_{\mathrm{C}} 28.0,28.2,28.5,31.8,53.2$, 123.6, 138.4, 147.5, 164.3. Anal. Calcd for $\mathrm{C}_{17} \mathrm{H}_{23} \mathrm{~N}_{9} \mathrm{Br}_{2}$ : C, 39.78; H, 4.52; N, 24.56\%. Found: C, $39.79 ; \mathrm{H}, 4.54 ; \mathrm{N}, 24.51 \%$.

2-[2-(7-Bromoheptyl)-2H-tetrazol-5-yl]-6-[1-(7-bromoheptyl)-1H-tetrazol-5-yl]-pyridine (3c)

White solid (1.32 g, $2.32 \mathrm{mmol}, 33 \%)$; mp 64-66 ${ }^{\circ} \mathrm{C} ; R_{f}=0.53$ (60:40 petroleum ether/ethyl acetate); IR ( $\left.\mathrm{KBr}, \mathrm{cm}^{-1}\right): 2923,2857,1653(>\mathrm{C}=\mathrm{N}-), 1581(-\mathrm{N}=\mathrm{N}-), 1464(\mathrm{C}=\mathrm{N}$, pyridine), 1434, 1261; ${ }^{1} \mathrm{H}$ NMR $\left(300 \mathrm{MHz}, \mathrm{CDCl}_{3}\right): \delta_{\mathrm{H}} 1.41\left(12 \mathrm{H}, \mathrm{m}, \mathrm{CH}_{2}\right), 1.83\left(4 \mathrm{H}, \mathrm{m}, \mathrm{CH}_{2}\right), 2.09(4 \mathrm{H}, \mathrm{m}$, $\left.\mathrm{CH}_{2}\right), 3.40\left(4 \mathrm{H}, \mathrm{m}, \mathrm{CH}_{2} \mathrm{Br}\right), 4.73\left(2 \mathrm{H}, \mathrm{t}, J=7.1 \mathrm{~Hz}, \mathrm{CH}_{2} \mathrm{~N} 2\right), 5.14\left(2 \mathrm{H}, \mathrm{t}, J=7.4 \mathrm{~Hz}, \mathrm{CH}_{2} \mathrm{~N} 1\right)$, $8.10(1 \mathrm{H}, \mathrm{t}, J=7.8 \mathrm{~Hz}, \mathrm{py} H), 8.36(1 \mathrm{H}, \mathrm{d}, J=6.8 \mathrm{~Hz}, \mathrm{py} H), 8.48(1 \mathrm{H}, \mathrm{d}, J=6.8 \mathrm{~Hz}, \mathrm{py} H) ;{ }^{13} \mathrm{C}$ NMR (75.4 MHz, $\left.\mathrm{CDCl}_{3}\right): \delta_{\mathrm{C}} 26.1,26.2,27.8,27.9,28.1,28.2,29.3,30.0,32.5,32.6,33.8,33.9$, 50.1, 53.5, 123.8, 125.1, 138.8, 145.2, 146.9, 151.2, 164.0. Anal. Calcd for $\mathrm{C}_{21} \mathrm{H}_{31} \mathrm{~N}_{9} \mathrm{Br}_{2}$ : C, 44.30; H, 5.49; N, 22.14\%. Found: C, 44.36; H, 5.54; N, 22.17\%.

2,6-Bis-[2-(7-bromoheptyl)-2H-tetrazol-5-yl]-pyridine (4c)

White solid $(0.20 \mathrm{~g}, 0.35 \mathrm{mmol}, 5 \%)$; mp 70-72 ${ }^{\circ} \mathrm{C} ; R_{f}=0.43$ (60:40 petroleum ether/ethyl acetate); IR (KBr, $\left.\mathrm{cm}^{-1}\right): 2928,2856,1653(>\mathrm{C}=\mathrm{N}-), 1581(-\mathrm{N}=\mathrm{N}-), 1463(\mathrm{C}=\mathrm{N}$, pyridine $), 1430$, 
1260; ${ }^{1} \mathrm{H}$ NMR $\left(300 \mathrm{MHz}, \mathrm{CDCl}_{3}\right): \delta_{\mathrm{H}} 1.37\left(12 \mathrm{H}, \mathrm{m}, \mathrm{CH}_{2}\right), 1.89\left(4 \mathrm{H}, \mathrm{m}, \mathrm{CH}_{2}\right), 2.11(4 \mathrm{H}, \mathrm{m}$, $\left.\mathrm{CH}_{2}\right), 3.44\left(4 \mathrm{H}, \mathrm{t}, J=7.3 \mathrm{~Hz}, \mathrm{CH}_{2} \mathrm{Br}\right), 4.76\left(4 \mathrm{H}, \mathrm{t}, J=7.3 \mathrm{~Hz}, \mathrm{CH}_{2} \mathrm{~N}\right), 8.12(1 \mathrm{H}, \mathrm{t}, J=7.7 \mathrm{~Hz}$, pyH), $8.36(2 \mathrm{H}, \mathrm{d}, J=7.8 \mathrm{~Hz}, \mathrm{py} H) ;{ }^{13} \mathrm{C} \mathrm{NMR}\left(75.4 \mathrm{MHz}, \mathrm{CDCl}_{3}\right): \delta_{\mathrm{C}} 27.2,28.6,28.7,29.8$, 32.7, 34.1, 53.6, 123.5, 138.3, 147.6, 164.2. Anal. Calcd for $\mathrm{C}_{21} \mathrm{H}_{31} \mathrm{~N}_{9} \mathrm{Br}_{2}$ : C, 44.30; H, 5.49; $\mathrm{N}$, 22.14\%. Found: C, 44.26; H, 5.44; N, 22.09\%.

2-[2-(9-Bromononyl)-2H-tetrazol-5-yl]-6-[1-(9-bromononyl)-1H-tetrazol-5-yl]-pyridine (3d)

White solid (1.61 g, $2.6 \mathrm{mmol}, 36.7 \%)$; mp 51-53 ${ }^{\circ} \mathrm{C} ; R_{f}=0.67$ (60:40 petroleum ether/ethyl acetate); IR (KBr, cm $\left.{ }^{-1}\right): 2923,2857,1653(>\mathrm{C}=\mathrm{N}-), 1581(-\mathrm{N}=\mathrm{N}-), 1464(\mathrm{C}=\mathrm{N}$, pyridine), 1434, 1261; ${ }^{1} \mathrm{H}$ NMR $\left(300 \mathrm{MHz}, \mathrm{CDCl}_{3}\right): \delta_{\mathrm{H}} 1.34\left(12 \mathrm{H}, \mathrm{m}, \mathrm{CH}_{2}\right), 1.61\left(8 \mathrm{H}, \mathrm{m}, \mathrm{CH}_{2}\right), 1.83(4 \mathrm{H}, \mathrm{m}$, $\left.\mathrm{CH}_{2}\right), 2.08\left(4 \mathrm{H}, \mathrm{m}, \mathrm{CH}_{2}\right), 3.40\left(4 \mathrm{H}, \mathrm{m}, \mathrm{CH}_{2} \mathrm{Br}\right), 4.72\left(2 \mathrm{H}, \mathrm{t}, J=7.1 \mathrm{~Hz}, \mathrm{CH}_{2} \mathrm{~N} 2\right), 5.16(2 \mathrm{H}, \mathrm{t}, J=$ $\left.7.3 \mathrm{~Hz}, \mathrm{CH}_{2} \mathrm{~N} 1\right), 8.09(1 \mathrm{H}, \mathrm{t}, J=8.1 \mathrm{~Hz}, \mathrm{py} H), 8.36(1 \mathrm{H}, \mathrm{d}, J=7.8 \mathrm{~Hz}, \mathrm{py} H), 8.48(1 \mathrm{H}, \mathrm{d}, J=7.8$ $\mathrm{Hz}, \mathrm{py} H) ;{ }^{13} \mathrm{C} \mathrm{NMR}\left(75.4 \mathrm{MHz}, \mathrm{CDCl}_{3}\right): \delta_{\mathrm{C}} 24.7,24.8,24.9,25.0,25.1,25.1,25.2,25.3,25.3$, 25.4, 25.5, 26.4, 27.2, 28.9, 28.1, 29.7, 32.9, 49.7, 53.3, 123.9, 125.2, 138.7, 145.4, 146.8, 151.3, 164.4. Anal. Calcd for $\mathrm{C}_{25} \mathrm{H}_{39} \mathrm{~N}_{9} \mathrm{Br}_{2}$ : C, 48.01; H, 6.29; N, 20.16\%. Found: C, 48.06; H, 6.28; N, $20.19 \%$.

2,6-Bis-[2-(9-bromononyl)-2H-tetrazol-5-yl]-pyridine (4d)

White solid (0.20 g, $0.3 \mathrm{mmol}, 4.6 \%) ; \mathrm{mp} 58-60{ }^{\circ} \mathrm{C} ; R_{f}=0.54$ (60:40 petroleum ether/ethyl acetate); IR ( $\left.\mathrm{KBr}, \mathrm{cm}^{-1}\right)$ : 2925, 2855, $1651(>\mathrm{C}=\mathrm{N}-), 1582(-\mathrm{N}=\mathrm{N}-), 1460(\mathrm{C}=\mathrm{N}$, pyridine $), 1434$, 1261; ${ }^{1} \mathrm{H}$ NMR $\left(300 \mathrm{MHz}, \mathrm{CDCl}_{3}\right): \delta_{\mathrm{H}} 1.37\left(16 \mathrm{H}, \mathrm{m}, \mathrm{CH}_{2}\right), 1.61\left(4 \mathrm{H}, \mathrm{m}, \mathrm{CH}_{2}\right), 1.89(4 \mathrm{H}, \mathrm{m}$, $\left.\mathrm{CH}_{2}\right), 2.11\left(4 \mathrm{H}, \mathrm{m}, \mathrm{CH}_{2}\right), 3.40\left(4 \mathrm{H}, \mathrm{t}, J=7.1 \mathrm{~Hz}, \mathrm{CH}_{2} \mathrm{Br}\right), 4.72\left(4 \mathrm{H}, \mathrm{t}, J=7.1 \mathrm{~Hz}, \mathrm{CH}_{2} \mathrm{~N}\right), 8.12$ $(1 \mathrm{H}, \mathrm{t}, J=7.7 \mathrm{~Hz}, \mathrm{py} H), 8.36(2 \mathrm{H}, \mathrm{d}, J=7.8 \mathrm{~Hz}, \mathrm{py} H) ;{ }^{13} \mathrm{C} \mathrm{NMR}\left(75.4 \mathrm{MHz}, \mathrm{CDCl}_{3}\right): \delta_{\mathrm{C}} 26.3$, 26.8, 27.2, 28.6, 28.7, 29.8, 32.7, 34.0, 53.5, 123.5, 138.3, 147.6, 164.2. Anal. Calcd for $\mathrm{C}_{25} \mathrm{H}_{39} \mathrm{~N}_{9} \mathrm{Br}_{2}: \mathrm{C}, 48.01 ; \mathrm{H}, 6.29 ; \mathrm{N}, 20.16 \%$. Found: C, 48.10; H, 6.32; N, $20.21 \%$.

General Syntheses of di-pyridyl-tetra-tetrazole macrocycles (5a-d)

A mixture of $2(0.86 \mathrm{~g}, 4.0 \mathrm{mmol})$ and potassium carbonate $(2.78 \mathrm{~g}, 20.0 \mathrm{mmol})$ in anhydrous dimethylformamide $(50 \mathrm{ml})$ was stirred at $75{ }^{\circ} \mathrm{C}$ under a nitrogen atmosphere, then treated with 3a-d $(4.0 \mathrm{mmol})$ and stirred at $75{ }^{\circ} \mathrm{C}$ for 24 hours. The insoluble salts, which were removed from the cooled mixture by filtration, were washed with ethyl acetate. The combined washings and mother-liquor were evaporated under reduced pressure. The residue was dissolved in chloroform 
and chromatographed on a silica gel column using ethyl acetate:petroleum ether (70:30 v/v) as eluent to give a white solid. Only ${ }^{1} \mathrm{H}$ NMR data was obtained for all mixtures.

\section{Macrocycle 5a}

${ }^{1} \mathrm{H}$ NMR $\left(300 \mathrm{MHz}, \mathrm{CDCl}_{3}\right): \delta_{\mathrm{H}} 1.97\left(4 \mathrm{H}\right.$, br m, $\left.\mathrm{CH}_{2}\right), 4.75\left(4 \mathrm{H}\right.$, br t, $\left.\mathrm{CH}_{2} \mathrm{~N} 2\right), 5.27$ (4H,br t, $\left.\mathrm{CH}_{2} \mathrm{~N} 1\right), 8.15(2 \mathrm{H}$, br t, py $H), 8.35(2 \mathrm{H}$, br d, pyH $), 8.48$ (2H, br d, pyH).

\section{Macrocycle 5b}

${ }^{1} \mathrm{H}$ NMR $\left(300 \mathrm{MHz}, \mathrm{CDCl}_{3}\right): \delta_{\mathrm{H}} 1.42\left(8 \mathrm{H}\right.$, br m, $\left.\mathrm{CH}_{2}\right), 1.83\left(4 \mathrm{H}\right.$, br m, $\left.\mathrm{CH}_{2}\right), 4.79(4 \mathrm{H}$, br t, $\left.\mathrm{CH}_{2} \mathrm{~N} 2\right), 5.23\left(4 \mathrm{H}\right.$, br t, $\left.\mathrm{CH}_{2} \mathrm{~N} 1\right), 8.14(2 \mathrm{H}$, br t, pyH), $8.33(2 \mathrm{H}, \mathrm{br} \mathrm{d}, \mathrm{py} H), 8.50(2 \mathrm{H}, \mathrm{br} \mathrm{d}, \mathrm{py} H)$.

\section{Macrocycle 5c}

${ }^{1} \mathrm{H}$ NMR $\left(300 \mathrm{MHz}, \mathrm{CDCl}_{3}\right): \delta_{\mathrm{H}} 1.45\left(12 \mathrm{H}\right.$, br m, $\left.\mathrm{CH}_{2}\right), 1.79\left(8 \mathrm{H}\right.$, br m, $\left.\mathrm{CH}_{2}\right), 4.72(4 \mathrm{H}$, br t, $\left.\mathrm{CH}_{2} \mathrm{~N} 2\right), 5.30\left(4 \mathrm{H}\right.$, br t, $\left.\mathrm{CH}_{2} \mathrm{~N} 1\right), 8.18(2 \mathrm{H}$, br t, py $H), 8.39(2 \mathrm{H}, \mathrm{br} \mathrm{d}, \mathrm{py} H), 8.46(2 \mathrm{H}, \mathrm{br}$ d, py $H)$.

\section{Macrocycle 5d}

${ }^{1} \mathrm{H}$ NMR $\left(300 \mathrm{MHz}, \mathrm{CDCl}_{3}\right): \delta_{\mathrm{H}} 1.35\left(12 \mathrm{H}\right.$, br m, $\left.\mathrm{CH}_{2}\right), 1.65\left(8 \mathrm{H}\right.$, br m, $\left.\mathrm{CH}_{2}\right), 1.81(8 \mathrm{H}$, br m, $\left.\mathrm{CH}_{2}\right), 4.73\left(4 \mathrm{H}\right.$, br t, $\left.\mathrm{CH}_{2} \mathrm{~N} 2\right), 5.12\left(4 \mathrm{H}\right.$, br t, $\left.\mathrm{CH}_{2} \mathrm{~N} 1\right), 8.09(2 \mathrm{H}$, br t, pyH), $8.04(1 \mathrm{H}, \mathrm{d}, J=6.8$ $\mathrm{Hz}, \mathrm{py} H), 8.17(2 \mathrm{H}, \mathrm{m}, \operatorname{Ar} H), 8.31(1 \mathrm{H}, \mathrm{d}, J=6.7 \mathrm{~Hz}, \mathrm{py} H), 8.41(1 \mathrm{H}, \mathrm{s}, \operatorname{Ar} H)$.

General Syntheses of pyridyl-tetra-tetrazole macrocycles (7a-d)

A mixture of $6(0.86 \mathrm{~g}, 4.0 \mathrm{mmol})$ and potassium carbonate $(2.78 \mathrm{~g}, 20.0 \mathrm{mmol})$ in anhydrous dimethylformamide $(50 \mathrm{ml})$ was stirred at $75{ }^{\circ} \mathrm{C}$ under a nitrogen atmosphere, then treated with 3a-d $(4.0 \mathrm{mmol})$ and stirred at $75^{\circ} \mathrm{C}$ for 24 hours. The insoluble salts, which were removed from the cooled mixture by filtration, were washed with ethyl acetate. The residue was dissolved in chloroform and chromatographed on a silica gel column using ethyl acetate:petroleum ether $(70: 30 \mathrm{v} / \mathrm{v})$ as eluent to give the pyridine tetra-tetrazolophane macrocycles $(\mathbf{7 a - d})$.

\section{Macrocycle 7a}

White crystalline solid $(0.43 \mathrm{~g}, 0.84 \mathrm{mmol}, 21 \%)$; mp 210-212 ${ }^{\circ} \mathrm{C} ; R_{f}=0.03$ (50:50 petroleum ether/ethyl acetate); IR (KBr, cm $\left.{ }^{-1}\right): 2926,2851,1654(>\mathrm{C}=\mathrm{N}-), 1596(-\mathrm{N}=\mathrm{N}-), 1458(\mathrm{C}=\mathrm{N}$, pyridine), 1433, 1261; ${ }^{1} \mathrm{H}$ NMR (300 MHz, $\left.\mathrm{CDCl}_{3}\right): \delta_{\mathrm{H}} 1.67\left(4 \mathrm{H}, \mathrm{m}, \mathrm{CH}_{2}\right), 4.74\left(2 \mathrm{H}, \mathrm{m}, \mathrm{CH}_{2} \mathrm{~N} 2\right)$, $5.03\left(4 \mathrm{H}, \mathrm{m}, \mathrm{CH}_{2} \mathrm{~N} 2\right), 5.30\left(2 \mathrm{H}, \mathrm{t}, J=7.1 \mathrm{~Hz}, \mathrm{CH}_{2} \mathrm{~N} 1\right), 7.60(1 \mathrm{H}, \mathrm{t}, J=7.6 \mathrm{~Hz}, \operatorname{ArH}), 7.91(1 \mathrm{H}, \mathrm{t}$, $J=7.9 \mathrm{~Hz}, \mathrm{py} H), 8.04(1 \mathrm{H}, \mathrm{d}, J=6.8 \mathrm{~Hz}, \mathrm{py} H), 8.17(2 \mathrm{H}, \mathrm{m}, \operatorname{Ar} H), 8.31(1 \mathrm{H}, \mathrm{d}, J=6.7 \mathrm{~Hz}$, 
pyH), $8.41(1 \mathrm{H}, \mathrm{s}, \mathrm{Ar} H) ;{ }^{13} \mathrm{C} \mathrm{NMR}\left(75.4 \mathrm{MHz}, \mathrm{CDCl}_{3}\right): \delta_{\mathrm{C}} 29.4,29.7,46.1,49.4,50.4,51.3$, $123.9,125.7,125.8,127.8,128.1,128.2$, 128.8, 129.8, 138.7, 144.5, 146.8, 151.5, 163.9, 164.2, 164.6; HRMS $(\mathrm{M}+\mathrm{H})^{+}$calcd for $\mathrm{C}_{21} \mathrm{H}_{20} \mathrm{~N}_{17}=510.2009$, found $=510.2085$. Anal. Calcd for $\mathrm{C}_{21} \mathrm{H}_{19} \mathrm{~N}_{17}: \mathrm{C}, 49.51 ; \mathrm{H}, 3.76 ; \mathrm{N}, 46.74 \%$. Found: C, 49.62; H, 3.88; N, 46.91\%.

\section{Macrocycle 7b}

White crystalline solid $(0.45 \mathrm{~g}, 0.79 \mathrm{mmol}, 20 \%)$; mp $195-197{ }^{\circ} \mathrm{C} ; R_{f}=0.16(50: 50$ petroleum ether/ethyl acetate); IR (KBr, $\left.\mathrm{cm}^{-1}\right): 2925,2855,1654(>\mathrm{C}=\mathrm{N}-), 1596(-\mathrm{N}=\mathrm{N}-), 1458(\mathrm{C}=\mathrm{N}$, pyridine), 1433, 1261; ${ }^{1} \mathrm{H}$ NMR (300 $\left.\mathrm{MHz}, \mathrm{CDCl}_{3}\right): \delta_{\mathrm{H}} 1.64\left(4 \mathrm{H}, \mathrm{m}, \mathrm{CH}_{2}\right), 2.19\left(8 \mathrm{H}, \mathrm{m}, \mathrm{CH}_{2}\right)$, $4.74\left(6 \mathrm{H}, \mathrm{m}, \mathrm{CH}_{2} \mathrm{~N} 2\right), 5.10\left(2 \mathrm{H}, \mathrm{t}, J=7.2 \mathrm{~Hz}, \mathrm{CH}_{2} \mathrm{~N} 1\right), 7.68(1 \mathrm{H}, \mathrm{t}, J=7.8 \mathrm{~Hz}, \mathrm{ArH}), 7.94(1 \mathrm{H}, \mathrm{t}$, $J=7.9 \mathrm{~Hz}, \mathrm{py} H), 8.13(1 \mathrm{H}, \mathrm{d}, J=6.8 \mathrm{~Hz}, \mathrm{py} H), 8.31(2 \mathrm{H}, \mathrm{m}, \operatorname{Ar} H), 8.40(1 \mathrm{H}, \mathrm{d}, J=6.8 \mathrm{~Hz}$, pyH), $8.69(1 \mathrm{H}, \mathrm{s}, \mathrm{Ar} H) ;{ }^{13} \mathrm{C} \mathrm{NMR}\left(75.4 \mathrm{MHz}, \mathrm{CDCl}_{3}\right): \delta_{\mathrm{C}} 23.4,23.5,28.1,28.3,28.8,29.4$, 49.7, 52.3, 53.0, 53.1, 123.8, 125.2, 125.5, 128.0, 128.2, 128.3, 128.4, 129.7, 138.6, 145.0, 146.7, 151.4, 164.0, 164.2, 164.6; HRMS $(\mathrm{M}+\mathrm{H})^{+}$calcd for $\mathrm{C}_{25} \mathrm{H}_{28} \mathrm{~N}_{17}=566.2635$, found $=566.2695$. Anal. Calcd for $\mathrm{C}_{25} \mathrm{H}_{27} \mathrm{~N}_{17}$ : C, 53.09; H, 4.81; N, 42.10\%. Found: C, 52.89; H, 4.71; N, 42.54\%.

\section{Macrocycle 7c}

White crystalline solid $(0.43 \mathrm{~g}, 0.69 \mathrm{mmol}, 17.3 \%) ; \mathrm{mp} 185-187{ }^{\circ} \mathrm{C} ; R_{f}=0.35$ (50:50 petroleum ether/ethyl acetate); IR (KBr, cm $\left.{ }^{-1}\right): 2924,2855,1658(>\mathrm{C}=\mathrm{N}-), 1597(-\mathrm{N}=\mathrm{N}-), 1459(\mathrm{C}=\mathrm{N}$, pyridine), 1432, 1261; ${ }^{1} \mathrm{H}$ NMR (300 MHz, $\left.\mathrm{CDCl}_{3}\right): \delta_{\mathrm{H}} 1.43\left(10 \mathrm{H}, \mathrm{m}, \mathrm{CH}_{2}\right), 2.08\left(10 \mathrm{H}, \mathrm{m}, \mathrm{CH}_{2}\right)$, $4.70\left(6 \mathrm{H}, \mathrm{m}, \mathrm{CH}_{2} \mathrm{~N} 2\right), 5.10\left(2 \mathrm{H}, \mathrm{t}, J=7.2 \mathrm{~Hz}, \mathrm{CH}_{2} \mathrm{~N} 1\right), 7.64(1 \mathrm{H}, \mathrm{t}, J=7.7 \mathrm{~Hz}, \operatorname{ArH}), 8.04(1 \mathrm{H}, \mathrm{t}$, $J=7.9 \mathrm{~Hz}, \mathrm{py} H), 8.25(1 \mathrm{H}, \mathrm{d}, J=7.0 \mathrm{~Hz}, \mathrm{py} H), 8.32(2 \mathrm{H}, \mathrm{m}, \operatorname{Ar} H), 8.44(1 \mathrm{H}, \mathrm{d}, J=6.9 \mathrm{~Hz}$, pyH), $8.83(1 \mathrm{H}, \mathrm{s}, \mathrm{Ar} H) ;{ }^{13} \mathrm{C} \mathrm{NMR}\left(75.4 \mathrm{MHz}, \mathrm{CDCl}_{3}\right): \delta_{\mathrm{C}} 25.6,25.8,26.1,26.2,27.6,28.4$, 28.8, 29.2, 29.7, 29.9, 49.9, 52.8, 53.2, 53.4, 123.8, 125.2, 125.3, 128.2, 128.3, 128.4, 128.5, $129.7,138.7,145.2,146.9,151.3,163.9,164.4,164.6$; HRMS $(\mathrm{M}+\mathrm{H})^{+}$calcd for $\mathrm{C}_{29} \mathrm{H}_{36} \mathrm{~N}_{17}=$ 622.3261, found $=622.3317$. Anal. Calcd for $\mathrm{C}_{29} \mathrm{H}_{35} \mathrm{~N}_{17}$ : C, 56.03; H, 5.67; N, 38.30\%. Found: C, 56.34; H, 5.83; N, 38.19\%.

\section{Macrocycle 7d}

White crystalline solid $(0.41 \mathrm{~g}, 0.61 \mathrm{mmol}, 15 \%) ; \mathrm{mp} 167-168{ }^{\circ} \mathrm{C} ; R_{f}=0.58$ (50:50 petroleum ether/ethyl acetate); IR ( $\left.\mathrm{KBr}, \mathrm{cm}^{-1}\right)$ : 2920, 2852, $1656(>\mathrm{C}=\mathrm{N}-), 1596(-\mathrm{N}=\mathrm{N}-), 1459(\mathrm{C}=\mathrm{N}$, pyridine), 1434, 1260; ${ }^{1} \mathrm{H}$ NMR (300 MHz, $\left.\mathrm{CDCl}_{3}\right): \delta_{\mathrm{H}} 1.33\left(22 \mathrm{H}, \mathrm{m}, \mathrm{CH}_{2}\right), 2.07\left(10 \mathrm{H}, \mathrm{m}, \mathrm{CH}_{2}\right)$, $4.69\left(6 \mathrm{H}, \mathrm{m}, \mathrm{CH}_{2} \mathrm{~N} 2\right), 5.12\left(2 \mathrm{H}, \mathrm{t}, J=7.3 \mathrm{~Hz}, \mathrm{CH}_{2} \mathrm{~N} 1\right), 7.64(1 \mathrm{H}, \mathrm{t}, J=7.2 \mathrm{~Hz}, \mathrm{ArH}), 8.07(1 \mathrm{H}, \mathrm{t}$, $J=7.8 \mathrm{~Hz}, \mathrm{py} H), 8.29(3 \mathrm{H}, \mathrm{m}, \mathrm{py} H \& \operatorname{Ar} H), 8.46(1 \mathrm{H}, \mathrm{d}, J=6.9 \mathrm{~Hz}, \mathrm{py} H), 8.89(1 \mathrm{H}, \mathrm{s}, \operatorname{Ar} H)$;

${ }^{13} \mathrm{C}$ NMR $\left(75.4 \mathrm{MHz}, \mathrm{CDCl}_{3}\right): \delta_{\mathrm{C}} 25.8,26.1,28.3,28.4,28.7,28.8,28.9,29.0,29.1,29.2,29.3$, 
29.7, 30.3, 50.1, 53.1, 53.3, 53.5, 123.7, 125.1, 125.2, 128.3, 128.4, 129.6, 138.7, 145.2, 146.9, 151.3, 163.9, 164.4, 164.5; HRMS $(\mathrm{M}+\mathrm{H})^{+}$calcd for $\mathrm{C}_{33} \mathrm{H}_{44} \mathrm{~N}_{17}=678.3887$, found $=678.3944$. Anal. Calcd for $\mathrm{C}_{33} \mathrm{H}_{43} \mathrm{~N}_{17}$ : C, 58.48; H, 6.39; N, 35.13\%. Found: C, 58.34; H, 6.43; N, 35.19\%.

\section{Crystallography}

Data for 3b and 7c were collected at 150(2)K on a Bruker Apex II CCD diffractometer using $\operatorname{Mo} K_{\alpha}$ radiation $(\lambda=0.71073 \AA)$. The structures were solved by direct methods and refined on $\mathrm{F}^{2}$ using all the reflections. ${ }^{20}$ All the non-hydrogen atoms were refined using anisotropic atomic displacement parameters and hydrogen atoms were inserted at calculated positions using a riding model. Crystallographic data for $\mathbf{3 b}$ and $\mathbf{7 c}$ has been deposited with the Cambridge Crystallographic Data Centre as supplementary publication number 799907 and 799908. Copies of the data can be obtained, free of charge, on application to CCDC, 12 Union Road, Cambridge CB2 1EZ, UK (Fax: +44(0)-1223-336033 or e-mail: deposit@ ccdc.cam.ac.uk).

Compound 3b. Crystal data: $\mathrm{C}_{17} \mathrm{H}_{23} \mathrm{Br}_{2} \mathrm{~N}_{9}, M=513.26$, orthorhombic, $a=9.99029(19), b=$ 10.2310(19), $c=40.898(8) \AA, U=4143.6(13) \AA^{3}$, space group $P b c a, Z=8, \mu=3.936 \mathrm{~mm}^{-1}, \rho_{\text {calc }}$ $=1.646 \mathrm{Mg} \cdot \mathrm{cm}^{-3} .28973$ data (3639 unique, $R_{\text {int }}=0.1246$ ) were measured in the range $1.99<\theta<$ $25.00^{\circ} . R_{1}(I>2 \sigma(I))=0.0883$ and $w R_{2}($ all data $)=0.2113$. Goodness of fit on $F^{2}=1.178$. CCDC No. 799907.

Compound 7c. Crystal data: $\mathrm{C}_{29} \mathrm{H}_{35} \mathrm{~N}_{17}, M=621.74$, monoclinic, $a=11.5821(13), b=$ 8.1191(9), $c=32.691(4) \AA, \beta=90.034(2)^{\mathrm{o}}, U=3074.1(6) \AA^{3}$, space group $\mathrm{P} 2{ }_{1} / \mathrm{c}, Z=4, \mu=$ $0.090 \mathrm{~mm}^{-1}, \rho_{\text {calc }}=1.343 \mathrm{Mg} \cdot \mathrm{cm}^{-3} .26150$ data (6321 unique, $R_{\text {int }}=0.0478$ ) were measured in the range $1.76<\theta<26.42^{\circ} . R_{1}(I>2 \sigma(I))=0.0432$ and $w R_{2}$ (all data) $=0.1087$. Goodness of fit on $F^{2}$ $=1.021$. CCDC No. 799908 .

\section{Acknowledgements}

We thank the Postgraduate R\&D Skills programme (Technological Sector Research, Strand I) and the Institute of Technology Tallaght PhD Continuation Fund for financial assistance.

\section{References}


1. Butler, R. N. in Comprehensive Heterocyclic Chemistry; Katritzky, A. R., Rees, C. W., Scriven, E. F. V., Eds.; Permagon: Oxford, U.K., 1996, Vol. 4.

2. Herr, R. J. Bioorg. \& Med. Chem. 2002, 10, 3379.

3. Zych, A. J.; Herr, R. J. PharmaChem., 2007, 6, 21.

4. Liu, B.; Qiu, Y.-C.; Peng, G.; Ma, L.; Jin, L.-M.; Cai, J.-B.; Deng, H. Inorg. Chem. Commun. 2009, 12, 1200.

5. Yang, G.-W.; Li, Q.-Y.; Zhou, Y.; Sha, P.; Ma, Y.-S.; Yuan, R.-X. Inorg. Chem. Commun. 2008, 11,723 .

6. Demko, Z. P.; Sharpless, K. B. J. Org. Chem., 2001, 66, 7945.

7. Himo, F.; Demko, Z. P.; Noodleman, L.; Sharpless, K. P. J. Am. Chem. Soc., 2003, 125, 9983.

8. Gundusola, A. S.; Chandra, K. L.; Perchellet, E. M.; Waters, A. M.; Perchellet, J.-P. H.; Rayat, S. Bioorg. Med. Chem. Lett., 2010, 20, 3920.

9. Habibi, D.; Nasrollahzadeh, M.; Faraji, A. R.; Bayat, Y. Tetrahedron, 2010, 66, 3866.

10. Lakshman, M. K.; Singh, M. K.; Parrish, D.; Balachandran, R.; Day, B. W. J. Org. Chem., 2010, 75, 2461.

11. Pachfule, P.; Das, R.; Poddar, P.; Banerjee, R. Cryst. Growth Des., 2010, 10, 2475.

12. Berndl, S.; Herzig, N.; Kele, P.; Lachmann, D.; Li, X.; Wolfbeis, O. S.; Wgaenknecht, H.-A. Bioconjugate Chem., 2009, 20, 558.

13. Klapötke, T. M.; Sabaté, C. M.; Rasp, M. Dalton Trans., 2009, 1825.

14. Yang, W.; Lin, X.; Blake, A. J.; Wilson, C.; Hubberstey, P.; Champness, N. R.; Schröder, M. CrystEngComm, 2009, 11, 67.

15. Zhao, H.; Qu, Z.-R.; Ye, H.-Y.; Xiong, R.-G. Chem. Soc. Rev., 2008, 37, 84.

16. Bond, A. D.; Fleming, A.; Kelleher, F.; McGinley, J.; Prajapati, V.; Skovsgaard, S. Tetrahedron, 2007, 63, 6835.

17. McGinley, J.; Fleming, A. J. Incl. Phenom. Macrocycl. Chem., 2008, 61, 1.

18. Bond, A. D.; Fleming, A.; Gaire, J.; Kelleher, F.; McGinley, J.; McKee, V. Tetrahedron, 2009, 65, 7942 .

19. Fleming, A.; Kelleher, F.; Mahon, M. F.; McGinley, J.; Prajapati, V. Tetrahedron, 2005, 61, 7002.

20. Sheldrick, G. M. Acta Cryst., 2008, A64, 112. 


\section{Synthesis and characterisation of macrocycles containing both tetrazole and pyridine functionalities}

Adrienne Fleming, Jackie Gaire, Fintan Kelleher, John McGinley, and Vickie McKee.

The syntheses of tetra-tetrazole
macrocycles containing at least one
2,6-bis(tetrazole)pyridine unit, linked
by a variety of $n$-alkyl $(n=3,5,7$ or 9
carbon atoms) chain lengths, are
described. There has been no previous
incorporation of the pyridine moiety
into a tetra-tetrazolophane macrocycle.

